\title{
Pacific Perspectives: Why study Europe's Middle Ages in Aotearoa New Zealand?
}

\begin{abstract}
It could be argued that the teaching of medieval history, while of intrinsic interest, is a colonial legacy that has very little relevance in the university curricula of a Pacific nation such as Aotearoa New Zealand. This chapter argues that, alongside the important role that an accurate understanding of Europe's past has to play in discrediting erroneous modern arguments, the teaching of medieval history remains relevant in Aotearoa for two key reasons. The first is that it enables a better understanding of New Zealand's colonial past and its legacies. The recent debate surrounding the naming of "The Crusaders" rugby team illustrates that understanding both the reality of the Middle Ages and the way in which the medieval was interpreted in the nineteenth and twentieth centuries is by no means unimportant. Similarly, the origins of New Zealand's legal and constitutional arrangements underline the continued relevance of establishing a sound understanding of the Middle Ages. Nevertheless, there is a second, possibly more important, reason for continuing to study the medieval in Aotearoa: the Middle Ages are, potentially, an excellent vehicle for better integrating Aotearoa's official policy of biculturalism into university curricula. To fulfil such a goal would require adjusting the way in which medieval history is taught at university to integrate comparison with Māori culture and values. By adopting such an approach, however, the chapter suggests that teaching Europe's Middle Ages will not only remain relevant to a society seeking to move beyond its colonial legacies but that it raises the possibility of introducing new and innovative approaches to medieval research.
\end{abstract}

Keywords: constitutional debate, common law, reception of the Middle Ages, teaching the Middle Ages, medieval legacies, Māori and Indigenous Studies, biculturalism, Christchurch (Aotearoa New Zealand), genealogy, Treaty of Waitangi, tertiary education

If we set aside the argument that the study of every subject is intrinsically interesting for its own sake, there seems, at least at first glance, very little reason why studying the history of medieval Europe should be relevant in the remote Pacific

\footnotetext{
Chris Jones, University of Canterbury, Christchurch, NZ, Department of History, Private Bag 4800, Christchurch 8140, New Zealand, chris.jones@canterbury.ac.nz Madi Williams, Ngāti Kuia, Ngāti Kōata, Ngāti Apa ki te Rā Tō; Ngāi Tahu Research Centre, University of Canterbury, Private Bag 4800, Christchurch 8140, New Zealand, madi.williams@canterbury.ac.nz 
nation of Aotearoa New Zealand. ${ }^{1}$ It would be difficult to argue, for example, that an understanding of the Middle Ages contributes in anything but the most tangential way to understanding the process of colonization. New Zealand was settled by Europeans relatively late. The immigrants who arrived in the nineteenth century were no less convinced of the superiority of their society than those who had arrived in the New World several centuries earlier. Yet, despite the influence of nineteenth-century evangelical movements, the values of New Zealand's colonizers were firmly defined by the Enlightenment and the Industrial Revolution, not the later Middle Ages and the Reformation. It could also be argued that, starting in the mid-twentieth century, and particularly since the 1970s, New Zealand has worked hard to shake off even that colonial legacy. The country has been particularly innovative in seeking to recognize and restore the rights of the indigenous Māori population, who had been subject to land confiscations and social marginalization in the previous century and a half. Indeed, the New Zealand of the twenty-first century increasingly looks to the Asia Pacific region rather than to Europe in general and - as it did up until the 1970s - to Britain specifically. China, alongside Australia and the European Union, is now one of the country's largest trading partners. ${ }^{2}$ And Aotearoa's demographic picture, while it remains dominated by Europeans and those of European descent, is shifting notably. Immigration and changing birth rates are projected over the next twenty years to lead to increases in the proportion of the population made up of those of Asian, Pacific Islander, and Māori descent. ${ }^{3}$ Why, then, should studying the Middle Ages matter in twenty-first century Aotearoa?

1 The authors are grateful for the ideas and comments they received from participants in the strand "Are the Middle Ages Relevant?" at the Leeds International Medieval Congress 2016 and the workshop "Teaching the European Middle Ages in Aotearoa New Zealand: Issues \& Opportunities" at the 2017 Tertiary Education Research in New Zealand conference held at Massey University. They would also like to thank Associate Professor Mike GRIMSHAW, Dr Valerie SoTARDI, and the anonymous peer reviewer for their helpful suggestions and comments. This article is an output of the project "Crossing Cultural Boundaries or the Embodiment of Colonialism? Teaching the Middle Ages in New Zealand", supported by a University of Canterbury Teaching Development Grant. Its publication was supported by a UC Open Access grant. Madi Williams' conference attendance was supported by the Ngāi Tahu Research Centre and School of Humanities \& Creative Arts.

2 Goods and services trade by country: Year ended December 2018, in: Stats NZ (4 March 2019), online: https://www.stats.govt.nz/information-releases/goods-and-services-trade-by-country-yearended-december-2018 (last accessed 15/05/2019).

3 "The medium projection indicates that between 2013 and 2038: The Māori, Asian, and Pacific ethnic populations will all increase their share of the total population in most regions, because their growth rates are higher than the region's total population." Subnational ethnic population projections: 2013(base)-2038 update, in: Stats NZ (3 October 2017), online: https://www.stats.govt.nz/in formation-releases/subnational-ethnic-population-projections-2013base2038-update (last accessed 15/05/2019). 
There are three reasons why understanding Europe's past not only matters but is important in a New Zealand context. The first was highlighted, tragically, by the Christchurch terror attacks of the 15 March 2019, which targeted two mosques and left fifty-one people dead. The country's initial response to the attack, embodied by its Prime Minister, Jacinda Ardern, was one of deep and genuine concern for the victims mixed with a rejection of the ideology that inspired such an atrocity. But the attacks also forced into the light a number of long-standing issues in New Zealand society. Most immediate was the country's inadequate firearms legislation, which had enabled the alleged perpetrator to purchase semi-automatic weapons. ${ }^{4}$ Another - perhaps more challenging - issue is racism, something Ardern herself acknowledged is a problem that exists in at least a section of New Zealand society. ${ }^{5}$ While the Middle Ages may appear to have very little immediate connection with such significant issues in a Pacific nation, it is worth highlighting that it is all too easy for those with racist ideologies to use medieval history to justify their own twisted goals. And, sadly, that appears to have been the case in this instance. ${ }^{6}$ The best way of combatting such misinterpretation is establishing a clear understanding of the reality of Europe's past.

The broader context in which the misuse of medieval imagery is employed by white supremacists is a subject highlighted in the introduction to this volume. This chapter will, however, focus on two other important issues. First, the Middle Ages remain a significant component of Aotearoa's constitutional, legal, and - notwithstanding the relative lateness of European settlement - its colonial history. Research into Europe's past can therefore provide clearer insight into some of the factors that have shaped - and continue to shape - debate and discussion around these issues in New Zealand society today. A second source of relevance is, however, to be found in the least likely of places: the study of the Middle Ages offers a potential pathway for New Zealanders to develop a clearer appreciation of the

4 A bill banning semi-automatic weapons was introduced within two weeks of the attack, on 1 April 2019. It passed its third reading on 10 April and became law on 11 April when it received royal assent: New Zealand Legislation, Arms (Prohibited Firearms, Magazines, and Parts) Amendment Bill, online: http://www.legislation.govt.nz/bill/government/2019/0125/6.0/LMS181180.html (last accessed 15/05/2019).

5 Racism 'something we're going to have to confront as a nation', in: 1News (18 March 2019), online: https://www.tvnz.co.nz/one-news/new-zealand/racism-something-were-going-have-confrontnation (last accessed 15/05/2019).

6 Gillian BRockwELL, The accused New Zealand shooter and an all-white Europe that never existed, in: Washington Post (16 March 2019), online: https://www.washingtonpost.com/history/2019/03/16/ac cused-new-zealand-shooter-an-all-white-europe-that-never-existed/ (last accessed 15/05/2019). The Chief Censor of the New Zealand Office of Film and Literature Classification has deemed footage from the film shot by the alleged perpetrator and his manifesto, "The Great Replacement", objectionable publications and banned possession, reading, or viewing of them in Aotearoa New Zealand. While it is possible to apply for an exemption on grounds of legitimate academic research, permission to view these items had not yet been received at the time of writing. 
principles that underpin the country's aspirations to develop a truly bicultural society in which Māori culture and values enjoy equal footing with those of Pākehā (New Zealanders of European descent). Paradoxically, medieval history's potential to contribute to the promotion of bicultural values is, perhaps, the most important reason why the study of Europe's Middle Ages remains relevant in Aotearoa today.

\section{Challenging Colonial Interpretations}

Following the 15 March attack, the name of Christchurch's local rugby team, "The Crusaders", and the question of whether or not that name should be changed, became the subject of intense debate in New Zealand. ${ }^{7}$ The team acquired its name in 1996 with the formation of the Super Rugby League. ${ }^{8}$ Its adoption was accompanied by a pre-match entertainment programme that evolved to include sword-wielding 'knights' astride horses decked out with crosses, flaming castles, and the use of Vangelis's "Conquest of Paradise" as theme music. It was a name and an identity that were chosen, at least in part, to reflect the city in which the team was based, in much the same way as the South Island's other Super Rugby team acquired the name "The Highlanders", a reflection of the city of Dunedin's strong Scottish roots. The controversy over the team's name is an excellent illustration of the relevance of the Middle Ages to the exploration of New Zealand's colonial history. It also provides an important tool for evaluating aspects of that history's legacy in contemporary society, and, in this case, the appropriateness or otherwise of retaining elements of it.

In the course of the nineteenth century, Christchurch became the key city in the Canterbury region, and remains today the South Island's largest population centre. ${ }^{9}$

7 For some of the varying views expressed in the New Zealand media: Kevin NoRQuAY, Super Rugby: The time for the Crusaders to put their name to the sword has arrived, in: Stuff (4 April 2019), online: https://www.stuff.co.nz/sport/opinion/111790180/super-rugby-the-time-for-the-crusaders-to-put-theirname-to-the-sword-has-arrived?rm=m (last accessed 15/05/2019); Duncan GARNER, Crusaders should hold the line, and keep their name, in: Stuff (5 April 2019), online: https://www.stuff.co.nz/sport/ rugby/super-rugby/111832155/crusaders-should-hold-the-line-and-keep-their-name (last accessed 15/ 05/2019). For an academic contribution to the debate see Geoff Troughton, Playing in overtime: why the Crusaders rugby team is right to rethink brand after Christchurch attack, in: The Conversation (4 April 2019), online: https://theconversation.com/playing-in-overtime-why-the-crusaders-rugby-team -is-right-to-rethink-brand-after-christchurch-attack-114826 (last accessed 15/05/2019).

8 For the establishment of Super Rugby: About Super Rugby, online: https://super.rugby/super rugby/about-super-rugby/ (last accessed 15/05/2019) and for "The Crusaders" franchise specifically: https://crusaders.co.nz/about-us/history (last accessed 15/05/2019).

9 For an overview: Geoffrey W. RicE, Christchurch Changing. An Illustrated History, 2nd ed. Christchurch 2008; for more detailed discussion, see the essays in: John Cookson / Graeme Dunstall (eds.), Southern Capital: Christchurch. Towards a city biography, 1850-2000, 
While the city's origins as a Church of England settlement did not immediately invoke the crusades, the prominence of the neo-gothic in its architecture, a feature that marked the city's skyline particularly strongly prior to the earthquakes of 2010-2011, was probably significant in cementing a connection between the city and Britain's Middle Ages in popular thought. This architecture, much of it the work of Benjamin MOUNTFORT (d. 1898), a pioneer of neo-gothic in New Zealand, defined the city's identity. ${ }^{10}$ Its legacy continues to be felt to this day: even though it collapsed in 2011, a stylized version of the city's Anglican cathedral, whose construction was supervised by MOUNTFORT, remains prominent in the logo of the Christchurch City Council.

The decision to embrace the neo-gothic in Christchurch's original civic plan reflected the way in which the Middle Ages came to be understood in popular nineteenth-century European thought. It was the same conception that inspired, on the one hand, William MORRIS, and, on the other, the statue of Richard I by Carlo MAROChETTI, which now stands outside the Palace of Westminster. The latter, in particular, represents the nineteenth-century's romanticized image of crusading, an image reinforced in the first half of the twentieth century by the contemporary colonial activities of Britain and France in the Levant. ${ }^{11}$ It certainly influenced the naming of two nineteenth-century English rugby clubs, "Saracens" (in 1876) and its local rival, the original "Crusaders". ${ }^{12}$ Historians, since at least the 1970s, and arguably before, have persistently sought to debunk these misrepresentations of both the Middle Ages and crusading in particular. Yet the image lingered on in Christchurch into the 1990s.

The decision to name Canterbury's rugby team "The Crusaders" was, then, shaped by a legacy of nineteenth-century colonial conceptions, conceptions that survived in an environment sheltered from the world in a pre-internet age by, to

Christchurch 2000. For the changing nature of the city following the 2010-2011 earthquakes: Katie PICKLES, Christchurch Ruptures, Wellington 2016.

10 For Mountfort specifically: Ian LochHeAd, A Dream of Spires: Benjamin Mountfort and the Gothic revival, Christchurch 1999. For the wider context: Chris BROoKs, The Gothic Revival, London 1999.

11 For a detailed introduction to this topic: Elizabeth SIBERRY, The New Crusaders. Images of the Crusades in the Nineteenth and Early Twentieth Centuries, Aldershot 2000.

12 The clubs merged into "Saracens" in 1878: Saracens, Saracens Club History, online: https://www. saracens.com/club/history/yourclub (last accessed 15/05/2019). The word 'Saracen' is Greek in origin and referred originally to a specific tribe; it was popularized in the medieval West as a generic term for Muslims: Bernard LEWIS, The Arabs in History, 6th ed. Oxford 1993, p. 4. For discussion of the medieval usage and for Christian attitudes towards Muslims and Islam more generally in the Middle Ages: John V. ToLAN, Saracens: Islam in the Medieval European Imagination, New York 2002. While undoubtedly also a colonial legacy, unlike "Crusaders", the name "Saracens" has fewer negative connotations today. 
borrow Geoffrey BLAINEY's phrase, the "tyranny of distance". ${ }^{13}$ Unchallenged by large-scale immigration from Muslim countries, these perceptions overshadowed modern scholarly assessments that underlined that the crusades were, in reality, an immensely complex form of religious warfare and one that often involved considerable brutality and bloodshed. ${ }^{14}$ This is despite the fact that, up until 2012, courses on the crusades were taught at the University of Canterbury by J. J. SAUNDERS (d. 1972), an internationally-recognized expert on the crusades and medieval Islam, and then by his student and successor, Geoffrey RicE, from 1974 to 2014. Both maintained an up-to-date curriculum and well-stocked library. Their influence was, however, limited to their students and a handful of teachers. Although RICE gave several public lectures on medieval Islam after 2001, the New Zealand public showed little appetite for engaging with modern scholarship on the crusades. Islam itself was also studied as part of the University's Religious Studies curriculum up until 2007; contemporary staff noted that, similarly, there was little interest in the topic. ${ }^{15}$ The decision to adopt the team's name can, in this light, be considered, at best, naïve; at worst, it demonstrates an alarming tendency to preference an accepted colonial narrative of the past over decades of scholarship. The extent to which outmoded attitudes linger on in New Zealand society today is indicated by the fact that when a recent 1News Colmar Brunton poll asked if people thought changing “The Crusaders's” name was the right thing to do following the mosque shootings, 76 per cent of respondents answered "no". ${ }^{16}$

The discussion concerning the suitability of the team's name in the wake of the events of the 15 March underlines why understanding Europe's medieval past, and the evolving scholarship connected with it, continues to be relevant in Aotearoa. It is a striking example that reveals the way in which long-standing misconceptions originating in the colonial era remain influential. Modern medieval scholarship has two things, in particular, to offer to this specific debate. First of all, it can reassure "The Crusaders" that in their choice of name they have not, inadvertently, been associating themselves with a racist agenda for the past twenty years (despite the ill-conceived and erroneous attempts of white supremacists to

13 BLAINEY coined the phrase in relation to Australia. While Aotearoa does not enjoy Australia's immense internal distances, many of his arguments are just as applicable: Geoffrey BLAINEY, The Tyranny of Distance. How distance shaped Australia’s history, 3rd ed. Sydney 2001.

14 With regard to the First Crusade, see, for example, Conor Kostick, The Siege of Jerusalem. Crusade and Conquest in 1099, London 2009.

15 The authors are grateful to Emeritus Professor Geoffrey RICE and Associate Professor Mike GRIMSHAW, who discussed these matters in private correspondence.

16 "The groups of people who were more likely to believe the Crusaders should keep the name included those living in Otago and Southland, National Party supporters and people aged 18-29." 'Striking' new poll indicates vast majority of Kiwis want Crusaders to keep their name, in: 1News (20 April 2019), online: https://www.tvnz.co.nz/one-news/new-zealand/striking-new-poll-indicatesvast-majority-kiwis-want-crusaders-keep-their-name (last accessed 15/05/2019). 
cast the crusades in racial terms). At the same time, the existence of the debate itself highlights the importance of a good understanding of supposedly arcane knowledge to modern social issues. It is not just about the need to unpick lingering, out-dated nineteenth-century colonial conceptions of the crusades; it draws underlying issues about racism to the surface. On the other hand, modern scholarship also suggests it is unlikely to be possible to 'reclaim' the name from a history steeped in religious conflict; the terms 'crusade' and 'crusaders' continue to resonate with the idea of western aggression in the Middle East today. ${ }^{17}$

While it is without doubt easy to be wise with hindsight, a deeper appreciation of what the crusades actually involved might well have led to different decisions when it came to naming the Christchurch rugby team. The issues facing "The Crusaders" highlight the value of understanding Europe's medieval past as part of a 'tool kit' that complements and deepens aspects of our understanding of Aotearoa's colonial history. It is an understanding that can help inform decisionmaking around how aspects of that past should be approached in the present day. Another example concerns the post-earthquake rebuild of Christchurch, in which efforts were made to locate synergies between Māori and western design features in the planning of a new convention centre for the city. ${ }^{18}$ Yet an appreciation of certain aspects of the Middle Ages also remains directly relevant to constitutional debates and the evolution of Aotearoa's legal system.

\section{Constitutional Debate \& Common Law}

The celebrations surrounding the eight-hundredth anniversary of Magna Carta in 2015 were a prominent reminder that New Zealand's legal and constitutional arrangements have strong roots in medieval Europe. Magna Carta was duly feted in Parliament, its anniversary marked by a number of events throughout the year, and the Charter and its relationship with Aotearoa the subject of considerable reflection in a volume published in 2017. ${ }^{19}$ The latter underlined the fact that while Magna

17 For discussion of the way in which these terms have come to be viewed in contemporary Islamic societies, see: Carole HILlENBRAND, The Crusades: Islamic Perspectives, Edinburgh 1999, pp. 589-616, and more recently the final chapter of Susanna A. Throop, The Crusades: An Epitome, Leeds 2019, pp. 177-186.

18 Chris Jones, The Great Hall, in: Te Maire TAU (ed.), Grand Narratives, Christchurch 2016, pp. 176-182.

19 For the - highly amusing - parliamentary debate: Motions - Magna Carta - 800th Anniversary, 16 June 2015, 706 NZPD 4385, online: https://www.parliament.nz/en/pb/hansard-debates/rhr/docu ment/51HansD_20150616_00000008/motions-magna-carta-800th-anniversary (last accessed 15/05/ 2019). For a summary of events throughout the anniversary year: Magna Carta $800 \mathrm{NZ}$, online: https://magnacartanz.wordpress.com/ (last accessed 15/05/2019). For a series of essays that reflect 
Carta has frequently failed to prove effective when cited by litigants-in-person, ${ }^{20}$ it is by no means irrelevant in New Zealand. Quite apart from its constitutional role - as interpreted by the seventeenth-century legal scholar and parliamentarian Sir Edward COKE - as a guarantor of freedom from arbitrary action by the state, the Charter offers at least one alternative pathway, legal pluralism, for the settlement of ongoing contention between the government and Māori. The significance of this pathway is that it is embedded within existing, albeit much neglected, constitutional structures. ${ }^{21}$

The 1988 Imperial Laws Application Act makes clear that Magna Carta, at least in the form it was enacted in 1297, is only one of a number of medieval statutes that remain in force in Aotearoa today. They range from the first Statute of Westminster (1275) to Edward III's 1368 legislation regarding the observation of due process. ${ }^{22}$ The 1988 act also includes the provision that: "the common law of England (including the principles and rules of equity), so far as it was part of the laws of New Zealand immediately before the commencement of this Act, shall continue to be part of the laws of New Zealand." 23 The latter places Aotearoa's legal system in a tradition with roots at least as deep as the thought of the twelfth- and thirteenthcentury jurists GLANVILL and BRACTON.

While it could be argued that an understanding of the Middle Ages remains relevant in Aotearoa because it has the potential to inform our understanding of contemporary law, few lawyers today are likely to find such esoteric knowledge necessary to go about their daily business. You do not, for example, need to understand the complexities of the origins of the modern trust to establish one. ${ }^{24}$ Where it would be difficult to

on the history of Magna Carta in New Zealand, its current status, and its possible future relevance see: Stephen WINTER / Chris Jones (eds.), Magna Carta and New Zealand - History, Law and Politics in Aotearoa, Cham 2017.

20 Lindsay BREACH, The Utility of a Medieval Charter in New Zealand Litigation: The Case of the Magna Carta, in: WinTER / Jones (note 19), pp. 161-180.

21 For its constitutional role: Chris Jones / Stephen WinTER, “ . . a document of our times.” Magna Carta in Aotearoa New Zealand, in: WINTER / JONES (note 19), pp. 3-20. For the Charter as a model for legal pluralism: Chris JoNEs, Mana and Magna Carta. Locating New Legacies in a Post-Colonial Society, in: ibid., pp. 229-251.

22 Following Schedule 1 of the act, the medieval statutes that remain in force are: "(1275) 3 Edw 1, c 1 - (Statutes of Westminster the First): so much of that Act as is stated in the words 'The King willeth and commandeth ... that common right be done to all, as well poor as rich, without respect of persons.', [being the English translation of part of the authentic text of that Act as it appears in the edition called Statutes of the Realm]; (1297) 25 Edw 1 (Magna Carta), c 29; (1351) 25 Edw 3, St 5, c 4; (1354) $28 \mathrm{Edw} 3$, c 3; (1368) $42 \mathrm{Edw} 3$, c 3.” Imperial Laws Application Act 1988 (reprint as at 26 March 2015), online: http://www.legislation.govt.nz/act/public/1988/0112/latest/whole. html\#DLM135078 (last accessed 15/05/2019).

23 Ibid.

24 Although such research is certainly worthwhile for its own sake: see, for one example, Lindsay BREACH, The development of the use and the origins of the modern trust: Maitland's thesis, the crusades, and beyond (unpublished PhD thesis, University of Canterbury, 2018). 
argue against the relevance of an understanding of the Middle Ages, however, is in constitutional debate. Although the 1840 Treaty of Waitangi between the Crown and Māori is rightly considered New Zealand's key founding document, ${ }^{25}$ the continued importance of Magna Carta alone justifies an engagement with the medieval context in which the latter was shaped. Indeed, one recent attempt to frame a new written constitution for the country, written by a former Prime Minister, begins by giving Magna Carta considerable prominence: "We the people of Aotearoa New Zealand: Express our desire to build upon our rich constitutional culture and heritage that includes the Magna Carta 1215 ... " ${ }^{26}$ And if the time limits set by the term 'medieval' are considered particularly elastic, one area beyond the 1988 act where otherwise abstruse knowledge appears relevant to constitutional issues is New Zealand's anomalous retention of the title "Defender of the Faith" as part of the style of its head of state. While it was excised from, for example, Elizabeth II's style as Queen of Australia, the title was consciously retained in New Zealand in 1974, as it was at an earlier date in the United Kingdom and Canada. ${ }^{27}$

While knowledge of the Middle Ages remains relevant to navigating the complexities of Aotearoa's unwritten constitution and legal system - perhaps to an extent that is sometimes underestimated - it would be reasonable to argue that for most New Zealanders such issues are unlikely to intrude heavily, if at all, into their daily lives. Aotearoa is such a state that you do not need to understand the technicalities - or even the broad brush stokes - of its constitutional arrangements to live here. ${ }^{28}$ While greater knowledge of constitutional matters among the population could be considered to contribute to the long-term health of any democracy, the fact that voter turnout in recent elections (77 \%) was well above the OECD average (69 \%) suggests that New Zealand's democratic institutions are in robust health. Similarly, the level of civic engagement is above the OECD average, and, while not comparable to its Australian neighbour, easily outstrips that of many European

25 Claudia ORANGE, The Treaty of Waitangi, Wellington 2011.

26 Geoffrey Palmer / Andrew ButleR, A Constitution for Aotearoa New Zealand, Wellington 2016, p. 34. For Aotearoa's current constitutional arrangements: Kenneth KeITH, An Introduction to the Foundations of the Current Form of Government (1990, updated 2008 and 2017), online: http://gg. govt.nz/role/constofnz/intro (last accessed 15/05/2019).

27 This particular constitutional quirk is discussed in more detail as part of an examination of the oldest New Zealand copy of Henry VIII's Assertio septem sacramentorum, the text in connection with which the title was originally granted: Chris JonES, Henry VIII, Defence of the Seven Sacraments, in: Chris JonEs / Bronwyn MATTHEws / Jennifer ClEMENT (eds.), Treasures of the University of Canterbury Library, Christchurch 2011, pp. 141-144 and 241-242.

28 One of the authors applied for and became a New Zealand citizen in 2015; the process did not involve any consideration of the country's constitutional arrangements beyond establishing that the applicant was aware that Elizabeth II was the head of state in her capacity as Queen of New Zealand. 
countries including France, Germany, and the United Kingdom. ${ }^{29}$ However, the decision of a 2015 referendum to reject any changes to the national flag is only one indicator that, despite the vibrancy of New Zealand's democracy, there is little appetite for constitutional change. As such, it seems likely that the relationship between certain elements of Aotearoa's constitution and their medieval origins will remain the preserve of a few specialists. However, there is one area in which knowledge of Europe's medieval past may yet prove to be of considerable relevance to a much broader demographic: the implementation of biculturalism.

\section{Biculturalism \& the University Curriculum}

New Zealand's official policy of biculturalism seems, initially, the most unlikely of places to locate the principal - or indeed any - relevance for the study of Europe's medieval past in Aotearoa. Biculturalism, as the term is understood in a New Zealand context, is uniquely connected with establishing parity between the culture of the indigenous Māori peoples and the settler culture; it is not to be confused with multiculturalism, which New Zealand embraces but which is a quite separate issue. The country's bicultural policy deliberately and consciously sets Māori culture apart as distinct from all other cultures. As a policy, biculturalism arose as part of wider attempts to redress the situation that resulted from the failure of New Zealand's government to honour the Treaty of Waitangi, the agreement between the British Crown and the islands' tribes that has come, as was noted above, to be regarded as the country's most important founding document. The policy can be defined broadly as "a partnership and respectful relationships between the two treaty partners, Māori and the Crown". ${ }^{30}$ The adoption of a bicultural policy has considerable implications for New Zealand society, which are reflected in ongoing debates concerning the nature of, for example, Māori rights to specific representation as Māori, and not simply as citizens. Its most obvious impact on contemporary poli-

29 Data from the OECD Better Life Index, New Zealand (2017), online: http://www.oecdbetterlifein dex.org/countries/new-zealand/ (last accessed 15/05/2019), which also notes "the level of stakeholder engagement [in Aotearoa] in developing regulations is 2.5 (on a scale between 0 and 4); slightly higher than the OECD average of 2.4."

30 Diane GoRDON-BuRNS / Leeanne CAMPBELL, Inakitia rawatia hei kakano mō apōpō: Students encounter with bicultural commitment, Ako Aotearoa (Southern Regional Hub) (May 2014), p. 10, online: https://ako.ac.nz/assets/Knowledge-centre/RHPF-s1101-Students-encounter-with-biculturalcommitment/c4468ed818/RESEARCH-REPORT-Inakitia-Rawatia-hei-Kakano-mo-Apopo-Students-Encounter-with-Bicultural-Commitment.pdf (last accessed 15/05/2019). 
tics is the maintenance of a separate Māori electoral roll, one whose membership is defined by tribal affiliation, and the continued reservation of seats in Parliament specifically for Māori. ${ }^{31}$

A key turning point in New Zealand's race relations occurred in the 1970s with the 'Māori Renaissance'. ${ }^{32}$ This saw an increase in advocacy - and subsequently awareness - of the dissatisfaction regarding the marginalization, culturally, economically, and politically, of Māori. This recognition was combined with an increasing drive to honour the promises of the Treaty. ${ }^{33}$ These factors pressured the government of the day into adopting an official "bicultural" approach in the 1980s. ${ }^{34}$ In fact, the situation in Aotearoa, as Keith SULLIVAN put it, "demands primarily a bicultural framework". ${ }^{35}$ The policy of biculturalism that emerged was defined by four key principles: it "is an equal partnership between two groups that values and supports cultural diversity, Māori are acknowledged as the tangata whenua, the original inhabitants of Aotearoa/New Zealand", and it has a focus on "redressing past injustices and re-empowering the indigenous people". ${ }^{36}$ The move to a policy of biculturalism was highlighted by the official adoption of 'Aotearoa / New Zealand', in place of 'New Zealand', as the name of the country. ${ }^{37}$ Greater emphasis was placed on the Treaty of Waitangi as a founding document, and the Treaty became a "focal point for biculturalism". 38

The move towards biculturalism is not embraced by all. One example is the ongoing debate over the existence of separate Māori seats in Parliament: New Zealand First, the party of the current Deputy Prime Minister, Winston Peters, favoured a referendum on their continued existence in 2018 and has, in the past, advocated their abolition. ${ }^{39}$ New Zealand could be characterized as a reluctantly bicultural nation, one that struggles to deal with the continuing effects of colonization. This is in part due to the fact that many New Zealanders are uncomfortable with the truth of

31 For an overview: Māori Representation, in: Electoral Commission New Zealand (14 August 2018), online: https://www.elections.org.nz/voting-system/maori-representation (last accessed 15/05/2019).

32 Steven Webster, Patrons of Maori Culture. Power, theory and ideology in the Maori Renaissance, Dunedin 1998, p. 28.

33 Neriko Musha DoERR, Meaningful inconsistencies. Bicultural nationhood, the free market, and schooling in Aotearoa/New Zealand, New York 2009, p. 9.

34 Aroha HARRIS (with Melissa Matutina WiLliAms), Rights and Revitalisation, 1970-1990, in: Tangata Whenua. An Illustrated History, Wellington 2014, pp. 416-451, here p. 437.

35 Keith Sullivan, Bicultural Education in Aotearoa / New Zealand. Establishing a Tauiwi Side to the Partnership, in: New Zealand Annual Review of Education 3 (1994), pp. 191-222, here p. 195.

36 Ibid.

37 DOERR (note 33), p. 10.

38 Ibid., p. 25.

39 Charlie DREAVER, Winston Peters wants 'two-part referendum' on Māori seats, in: Radio New Zealand (5 July 2018), online: https://www.radionz.co.nz/news/te-manu-korihi/361175/winstonpeters-wants-two-part-referendum-on-maori-seats (last accessed 15/05/2019). 
how New Zealand came to be and are consequently unwilling to engage with the past. History in New Zealand remains a contentious topic and involves, as Avril BELL put it, a strong desire to forget the "history of violence in the construction of the New Zealand nation-state." ${ }^{40}$ A denial of the truth of New Zealand's past is often accompanied by arguments in favour of the adoption of a multicultural, rather than a bicultural, approach. While no one would deny Aotearoa is becoming a society defined by more than simply two cultures - Māori and European for Māori the key role of the Treaty means that any first step remains establishing the bicultural relationship: "[no] other ethnic group here has had such an agreement [as the Treaty], so it has become a priority for Māori that, before issues of multiculturalism are addressed, the outstanding grievances of the tangata whenua, the original people of the land, must be settled."41

While New Zealand is officially a bicultural nation, it can be argued that there remains a lack of bicultural awareness and skills. Māori do not have a choice in whether or not to be bicultural due to the nature of contemporary Aotearoa, a country in which English is the primary language of communication and western culture predominates. Pākehā, on the other hand, have every choice, and many choose not to engage with biculturalism. This has created an ongoing problem for institutions such as Aotearoa's universities, all of which have a legal obligation to honour the Treaty of Waitangi. ${ }^{42}$ One approach to addressing this requirement is the incorporation of bicultural aims throughout the curricula, including into the study of medieval Europe.

The University of Canterbury, based in the city of Christchurch, has approached the challenge of meeting its Treaty obligations by officially recognizing "the special relationship with Ngāi Tahu and our commitment to explore opportunities to extend our common interest and strengths, for Ngāi Tahu and all Māori”. ${ }^{43}$ Ngāi Tahu are the tribe who hold the mana whenua over the majority of the South Island of New Zealand. Mana whenua is a broad concept that signifies territorial rights and authority over land. In addition to this, the University has created a series of graduate attributes, one of which is bicultural confidence and competence. This attribute has been defined as: "the ability to interact confidently and appropriately with persons

40 Avril Bell, We're Just New Zealanders, in: Paul Spoonley / David PeArson / Cluny MaCPHERSon (eds.), Nga Patai. Racism and Ethnic Relations in Aotearoa/New Zealand, Palmerston North 1996, pp. 144-158, here p. 152.

41 James RitchiE, Becoming Bicultural, Wellington 1992, pp. 7-8.

42 Section 181(b) of the Education Act 1989 (amended 1990) states that it is the duty of university councils: "To acknowledge the principles of the Treaty of Waitangi." Duties of Councils, Education Act 1989 (Reprint as at 21 December 2018), online: http://www.legislation.govt.nz/act/public/1989/ 0080/262.0/DLM184136.html (last accessed 15/05/2019).

43 Rautaki Whakawhanake Kaupapa Māori. Strategy for Māori Development, in: University of Canterbury (2012), online: https://www.canterbury.ac.nz/media/images/leadership-andgovernance/strategy_for_maori_development_2012.pdf (last accessed 15/05/2019). 
from a background that is different from one's own. It goes beyond an awareness of, or sensitivity to, another culture to include the ability to use that knowledge in cross-cultural situations." ${ }^{44}$ In theory, this attribute is intended to provide graduates with the transferable skills needed to engage and empathize with a variety of people from other backgrounds, both nationally and internationally. The adoption of this graduate attribute has led to the incorporation of bicultural aims throughout the University including into a range of courses. It is in this attempt to embed the attribute of bicultural competence at every level of the curriculum and to ensure students acquire it in the course of their time at university, that the study of Europe's Middle Ages becomes, potentially, highly relevant in a New Zealand context. Given the aims of the bicultural policy, such a claim undoubtedly appears, at first glance, paradoxical, if not perverse.

The 'natural' location in which to embed a bicultural component are courses offered by Māori and Indigenous Studies departments. Such departments can offer dedicated courses in this area. An example at Canterbury intended for first-year students would be the 100-level course MAOR108 Aotearoa: Introduction to New Zealand Treaty Society. ${ }^{45}$ A 100 -level course is a foundation course in a particular subject. However, while similar departments exist in all New Zealand universities, they sometimes struggle to attract a wide range of students. At Canterbury, the key groups that enrol in these classes are Māori themselves; international students, many of whom see such courses as an integral part of their 'New Zealand experience'; and students that are required to take the course as part of a specific degree. In 2017, enrolment data for Canterbury's MAOR108 course suggested that 71 per cent of students were Pākehā. ${ }^{46}$ While on the surface such a figure would suggest the University's efforts to inculcate bicultural competence and confidence as a graduate attribute is extremely

44 UC’s Bicultural Competence and Confidence Framework, in: Assistant Vice-Chancellor Māori’s Office, University of Canterbury (undated), online: https://www.canterbury.ac.nz/about/leader ship/senior-management-team/avc-maori/bicultural-competence-and-confidence-framework/ (last accessed 15/05/2019).

45 For the 2019 offering: MAOR108 Aotearoa: Introduction to New Zealand Treaty Society, online: https://www.canterbury.ac.nz/courseinfo/GetCourseDetails.aspx?course=MAOR108 (last accessed 15/05/2019). Although intended primarily for first years, students are able to take 100-level (introductory) courses at any time during their degree. Canterbury operates a points-based system, with the award of a Bachelor's degree based on the accumulation of 360 points from a mix of 15 and 30 point courses. While completion of a 100-level course in a particular topic area is usually a prerequisite to study that subject at a higher level, it is possible to 'add in' additional 100-level courses at any point in a degree.

46 Ethnicity has been determined based on the way students self-identify in University records. Two important caveats must be kept in mind. First, students often identify as members of more than one ethnicity; where one of those ethnicities was Māori the student has been counted as such. Second, where an enrolled student identified at least one ethnicity, that ethnicity has been taken into account even if they also ticked 'other' or 'not stated' (options that were allowed by the data collection tool). With this in mind, the percentages should be considered to indicate no more 
effective via this route, it is worth emphasizing that 78 per cent of the Pākehā students who took this particular course were in degree programmes where it was compulsory. Indeed, a rise in Pākehā students taking the paper is linked to degree schedules that make engagement with bicultural themes a requirement. For example, a large proportion of students taking MAOR108 in 2017 were enrolled in either the Bachelor of Criminal Justice or the Bachelor of Health Science, both of which require students to take a first-year Māori and indigenous Studies paper as part of their schedule. This is not to say that no Pākehā New Zealand students take these papers by choice, but this group are a minority. If the aim is to ensure that all students obtain the graduate attribute of bicultural competence and confidence, this creates a problem: while the necessary courses exist, many students do not choose to engage with them. If students are reluctant to take papers with a Māori and Indigenous focus, then one option is to introduce a requirement that all students take such a paper as part of their degree.

While the integration of required courses into degree programmes is certainly one approach that can address the University's aim of ensuring all students graduate with bicultural skills, it remains problematic: research indicates that compulsory courses are generally not well received by students. This is principally because, as Carol SCHICK put it, to "define something as compulsory is, in terms of the liberal discourse of freedom and human rights, to define it negatively. Compulsion is automatically rhetorically bad." 47 This point has been proven by SCHICK specifically in relation to a compulsory cross-cultural paper implemented in a Canadian university. ${ }^{48}$ An approach that incorporates compulsory papers presents particular challenges for the Bachelor of Arts where, traditionally, students in Aotearoa New Zealand have enjoyed considerable freedom of choice in the subjects they study. To date, the solution has been to assemble a list of courses that incorporate bicultural themes - Schedule $\mathrm{C}$ - and to require students to take at least one course from that list as part of their degree. ${ }^{49}$ Such an approach requires minimal engagement with biculturalism; it is inadequate for truly achieving the goal of ensuring all students engage meaningfully with the graduate attribute. A risk of this approach is the drawing of superficial links between one's own subject and biculturalism in order to adhere to institutional regulations. When this occurs it works against the aims of genuine biculturalism. There needs to be authentic engagement with the values of biculturalism for this approach to have any merit.

than general trends. The authors are grateful to Aotahi: School of Māori and Indigenous Studies for access to, and permission to use, course enrolment data for MAOR108.

47 Carol SснIск, Keeping the Ivory Tower White: Discourses of Racial Domination, in: Canadian Journal of Law and Society 15(2) (2000), pp. 70-90, here p. 73.

48 Ibid.

49 Schedule $\mathrm{C}$ to the Regulations for the Degree of Bachelor of Arts, Calendar, University of Canterbury (2019), online: https://www.canterbury.ac.nz/media/documents/regulations/academicregulations-2019-coa-BA.pdf (last accessed 15/05/2019). 
Further barriers to incorporating bi- or cross-cultural elements lie in the perceived threat such courses pose to students' own sense of self, identity, and nationhood. Might they not appear as a form of indoctrination and lead to concomitant resentment? An alternative may be to integrate bicultural skills and knowledge into existing courses. The integration approach has proven successful in relation to academic literacy skills; research has shown that "well-designed activities embedded within discipline based programmes are one highly effective way to promote acquisition of these skills." 50 The integration of the bicultural graduate attribute could take many forms. The bicultural competence and confidence mapping document outlines seven kaupapa (initiatives/concepts) that offer starting points to course designers: a process of self-reflection on the nature of 'knowledge' and 'norms'; the nature of contemporary Māori organizational structures; traditional and contemporary realities of Māori society; the Treaty of Waitangi and Aotearoa New Zealand's bicultural history; the processes of colonization and globalization; other indigenous models of development, knowledge, and behaviours; and application of bicultural competence and confidence in a chosen discipline and career. ${ }^{51}$ While some kaupapa may suit some courses more than others, the vital aspect to a successful programme would be to integrate ways of thinking that generate reflection. This is where the study of medieval Europe can play an important role; different ways of thinking and understanding the world can be explored and then applied to contemporary New Zealand society.

Māori culture and traditions remain strong in Aotearoa New Zealand. For those living and working in the country, it is essential to become familiar with and gain an understanding of that culture and traditions if for no other reason than it enjoys a unique, legally-protected position. However, there remain many New Zealanders who are unable, and/or unwilling, to understand Māori society on its own terms. While it would be preferable if all New Zealand students chose to engage in a positive manner with Māori culture, it is necessary to recognize three factors that militate against this. First, the continuing contention surrounding the colonization and subjugation of Māori; second, put simply, many Pākehā students do not consider the topic relevant and actively seek to avoid engaging with it; and, third, the way in which New Zealand history is taught in schools elides discussion of the wider context of history, culture, and colonization. ${ }^{52}$ It is here that the study of medieval Europe may offer a useful pathway to developing bicultural skills.

50 Cathy Gunn / Shari HeARne / Julie SibTHORPE, Right from the Start: A Rationale for Embedding Academic Literacy Skills in University Courses, in: Journal of University Teaching \& Literacy Practice 8 (1) (2011), online: https://ro.uow.edu.au/jutlp/vol8/iss1/6/ (last accessed 15/05/2019), p. 1.

51 UC's Bicultural Competence and Confidence Framework (note 44).

52 The authors are grateful to Associate Professor Mike GRIMSHAW for highlighting the importance of this third point. 


\section{Towards Teaching a History of Values}

If the study of medieval history is approached as an opportunity to learn about a different society on its own terms, rather than as an exploration of the origins of a distinctly western civilization and its development, then its relevance in a New Zealand context becomes clearer. Considered from such a vantage point, the study of medieval Europe has the potential to make a valuable contribution to the development of the skills needed to understand other cultures and societies. For it to do so, however, requires more than a conscious rejection of a 'whiggish' interpretation of 'history as progress'. The desirability of avoiding Herbert BUTTERFIELD's 'Whig' interpretation of history, laden with its tendency to distort our understanding of the past, is certainly something many - if by no means all - professional historians would keep foremost in their minds today. ${ }^{53}$ However, for medieval history to be relevant to biculturalism a deliberate decision is also required to move away from topics that are particularly prominent in the historiography, such as the history of institutions, administrative development, architectural evolution, etc.; indeed, any topic that is principally set by a potentially 'whiggish' modern agenda and in which the interests of historians, rather than the views of contemporaries, are the principal driver of enquiry. Instead, it requires a concerted effort to approach history from the perspective of those who lived it; its agenda must become the agenda of contemporaries, and history the reconstruction of the medieval mind-set to the extent such a thing is possible. Or, to put it another way, a medieval history that is relevant to biculturalism is an account that attempts to understand not what occurred and why, but what was perceived to be important by those who experienced it. Such an approach would certainly benefit from drawing on the new focus on topics such as race in a medieval context in recent historiography. ${ }^{54}$ This opens the door to understanding another society on its own terms, and it is this that is critical to establishing bicultural competence and confidence. In many ways, understanding any society that differs substantially from that of the modern western world, would be valuable in this regard. The world of medieval Europe, however, offers a particularly fruitful field for investigation because of the similarity between some aspects of the worldview of its inhabitants and Māori.

It is important to emphasize that there are no direct parallels to be established in a comparison of the medieval and the Māori. In fact, the greatest danger in an approach that employs medieval European history to explore biculturalism is that it may imply that Māori society can be explained by reference to medieval Europe.

53 For the 'Whig' interpretation of history as it has come to be understood: Michael BENTLEY, Modern Historiography. An Introduction, London 1999, pp. 62-70. And for BUTTERFIELD's original assessment: Herbert BuTTERFIELD, The Whig Interpretation of History, London 1931.

54 See for example: Geraldine Heng, The Invention of Race in the European Middle Ages, Cambridge 2018. 
This would be incorrect; the two societies evolved very differently and are distinct. Yet, at the same time, some of the values of medieval European society appear notably closer to those of the Māori world than they do to those of the modern West. ${ }^{55}$ By focussing on a 'history of values' or social norms that establishes that these differ from society to society, the medieval world can become a vehicle for understanding the concepts at the heart of bicultural competence. For the relevance of the study of the Middle Ages in this context to be realized fully, however, it is important to incorporate a 'layer' into the teaching process that explains the values of the medieval West to a New Zealand audience in terms of Māori values and concepts, highlighting the similarities and differences.

An exploration of European perceptions of genealogy in terms of the Māori concept of whakapapa offers one notable example of the type of approach that might be adopted. The University of Canterbury is fortunate to hold the only example in the southern hemisphere of a medieval genealogical roll. This fifteenthcentury, five-metre long English manuscript is a fascinating, unique item. It is certainly worthy of investigation in its own right. As such, it has been the focus of several recent published studies by Canterbury students and is the subject of the ongoing "Canterbury Roll Project", which, to date, has created a digital edition and translation. ${ }^{56}$ At the same time, its value as a teaching tool for bicultural competence is certainly as important as the rare opportunity it affords to introduce New Zealand students to a medieval manuscript. ${ }^{57}$ The roll functions as a window

55 For an introduction to the Māori worldview and further discussion of the value/dangers of drawing comparisons with medieval Europe: Madi WiLLIAMs, Polynesia, 900-1600, Leeds (forthcoming). 56 Christchurch, University of Canterbury, MS 1. See in particular: Maree SHIROTA, Royal Depositions and the 'Canterbury Roll', in: Parergon 32(2) (2015), pp. 39-61; Thandiwe PARKER, A Woman's Role. How Scribes Depicted Women On The Fifteenth-Century Canterbury Roll, in: Comitatus. A Journal of Medieval and Renaissance Studies 48(1) (2017), pp. 95-115. The new edition and translation, as well as introductory materials and a high definition digital facsimile, were created in collaboration with Canterbury University Press and UC's Arts Digital Lab. They are available, open access, as part of the ongoing Canterbury Roll Project, online: https://www.canterbury.ac.nz/canterburyroll (last accessed 15/05/2019). For the project: Mark BRIDGE, Medieval scroll gives up secrets from original Game of Thrones, in: The Times (29 January 2018), online: https://www.thetimes.co.uk/article/medieval-scrollgives-up-secrets-from-the-original-game-of-thrones-30z9mk0b3 (last accessed 15/15/2019); and for an academic assessment: Judith CollaRd, Review: Jones, Chris, Christopher Thomson, Maree Shirota, Elisabeth Rolston, Thandi Parker, and Jennifer Middendorf, eds, The Canterbury Roll - A Digital Edition, December 2017, <http://www.canterbury.ac.nz/canterburyroll>, Christchurch, Canterbury University Press, in: Parergon 35(2) (2018), pp. 215-216.

57 There are just over 180 manuscripts in New Zealand: Margaret M. MANion / Vera F. Vines / Christopher DE HAMEL, Medieval and Renaissance Manuscripts in New Zealand, Melbourne 1989. For a less complete earlier catalogue see: David M. TAYLOR, The Oldest Manuscripts in New Zealand, Wellington 1955. Detailed studies of New Zealand's holdings are limited, although the country's collectors are better served by contemporary scholarship. Two key volumes in which both manuscripts and collectors are explored are: Stephanie Hollis / Alexandra BARRATT (eds.), Migrations: Medieval Manuscripts in New Zealand, Newcastle 2007, and Chris JonEs (ed.), A Road 
onto the importance of genealogy in the medieval world and is, equally, a springboard to understanding the way in which the past was perceived in pre-Renaissance England. For Māori, the concept of whakapapa, that is the construction and tracing of genealogical relationships, remains part of the bedrock on which society is constructed: “At a simple level [whakapapa] means 'genealogy', but it also refers to the whole body of Māori knowledge and belief systems that reaches back to the 'atua' (gods), the archetypal heroes and tribal ancestors." 58 Every formal introduction continues to incorporate a mihi, in which the person introducing themselves establishes their whakapapa. While there are substantial differences between the spiritual importance (mana) attributed to a recorded whakapapa and a medieval genealogical document, study of the latter can introduce a key idea: the importance of genealogy and the tracing of genealogical roots to a society. Comparing that genealogy with the Māori conception of whakapapa, an approach that is today integrated into 200/ 300-level courses at Canterbury, establishes the importance of genealogy as a value across the two societies while creating an opportunity to discuss the differences and similarities in the way in which those values were - and are - understood.

Canterbury's 100-level introduction to medieval history, HIST133 Medieval Europe: From Rome to the Black Death, has remained a consistently popular 'gateway' course, maintaining, since 2014, the largest enrolment of any History course at Canterbury. It remains, simultaneously, non-compulsory and one of four History 100-level options offered annually, the completion of any one of which enables progression to higher-level courses in the subject. Its enrolment is also, overwhelmingly, dominated by Pākehā students in the Bachelor of Arts degree, students whose only required encounter with biculturalism is participation in a Schedule C course. Approaching the teaching of HIST133 with a focus on the 'history of values', rather than adopting a traditional curriculum driven by historiographical debates, offers the opportunity, without introducing compulsory courses, to deepen the engagement with biculturalism for students whose experience of the graduate attribute might otherwise be fleeting.

While by no means a direct substitute for engagement with the Māori world, the type of approach described above effectively achieves three goals: the teaching of European history on its own terms; the establishment of bicultural competence and confidence; and the opening up of a new doorway onto a topic - the Māori worldview - that some students may have considered irrelevant. A process of engagement

Less Travelled: The Medieval and Early Modern World Reflected in New Zealand Collections, in: Parergon, Special Issue 32(2) (2015), pp. 1-250. For objets d'art and paintings, the only general survey is: Mary KISLER, Angels \& Aristocrats: Early European Art in New Zealand Public Collections, Auckland 2010.

58 For an introduction to an example of recorded whakapapa from the Canterbury region: Te Maire TAU, Whakapapa Books, in: Jones / MATTHEWs / CLEMENT (note 27), pp. 91-97 and 236 (quote: p. 95). See also: Hirini Moko MEAD, Tikanga Māori. Living by Māori Values, Wellington 2003. 
with Māori perspectives and an exploration of the history of values has the added benefit of potentially enabling Aotearoa-based medieval historians to generate new questions about their own field stimulated by an encounter with Māori concepts, questions they might otherwise not have asked. One early example of this is the increasing number of student-led projects at Canterbury - often employing the Canterbury Roll as a source - with a focus on digging deeper into European conceptions of genealogy and its significance for medieval society.

$\star \star \star$

The appalling events that took place in Christchurch on 15 March 2019 are a reminder that establishing a deeper understanding of medieval Europe is as important in Aotearoa New Zealand as it is elsewhere in the world. The best means of contesting the use of medieval imagery by white supremacists is to provide society with the tools to ensure that such views are not able to go unchallenged. More generally, the medieval also remains relevant to those interested in understanding New Zealand's unique colonial past and its constitutional and legal arrangements. Yet, it is the emphasis placed upon the importance of promoting a concept of biculturalism unique to New Zealand society, that, paradoxically, makes the study of the European Middle Ages most relevant in a Pacific nation. It is certainly possible to continue to teach the Middle Ages in Aotearoa much as they are taught in Europe and North America. Yet doing so risks the subject becoming less and less relevant as New Zealand society moves further away from its colonial roots. In order to realize fully the relevance of their subject in Aotearoa, medievalists need to embrace different approaches. Those approaches should favour engagement with Māori culture over participation in historiographical debates whose agendas are often shaped in very different environments.

It is to be hoped that, by embracing an agenda shaped by Aotearoa, New Zealand's medievalists are, in turn, able to bring new and unique perspectives to the wider community of medieval scholars. Whakapapa offers only one example of the way in which bicultural points of comparison can be raised in the course of studying medieval history. Topics are many and varied. They range from the process by which a predominantly oral culture transitioned into a written culture, to the way in which customary title - a concept understood as take whenua in the Māori world - developed into 'legal', documented forms of land tenure. The study of medieval Europe remains, then, relevant for the opportunity that it offers to introduce a generation of students to the graduate attribute of cultural competence and confidence. At the same time, the teaching of European history can itself be enriched by a comparative approach that has the potential to introduce new questions. 
